\title{
Modern precipitation of ferromanganese oxides and metal accumulation during 12-15-yr on-site experiment at NW Pacific seamounts
}

\author{
A. USUI * , H. HiNO1, D. SUZUSHIMA1, T. \\ KASHIWABARA2, TOMIOKA 2 AND K. YAMAOKA3
}

1 Kochi Core Center, Kochi University, Akebono, Kochi, 7808520 (*correspondence:a-usui@Kochi-u.ac.jp) 2JAMSTEC, Yokosuka, Japan

${ }_{3}$ Geological Survey of Japan, Tsukuba

The model suggests reconsideration on chemical forms of $\mathrm{Mn}$ and $\mathrm{Fe}$ in normal sea waters with varying redox potential at the depths. The proposed model indicates a modern continuous precipitation when both $\mathrm{Mn}$ and $\mathrm{Fe}$ are supplied to ambient sea waters. The particulate is thus the smallest unique constituent of hydrogenetic ferromanganese crusts and nodule deposit of the Neogene to the Recent at full water depths in oxic deep-sea environments at all oceans. These hydrogenetic particulates, Fe-Mn oxide forms the piled ferromanganese crusts and nodules at a wide-range of depths including OMZ. The particulate is thus the smallest unique constituent of ferromanganese crust and nodule deposit of the Neogene to modern age at full water depths of oxic deep-sea environments at all oceans. The results indicated a substantial ultra-slow but continuous growth of hydrogenetic Fe-Mn minerals when both $\mathrm{Mn}$ and $\mathrm{Fe}$ are supplied into the bottom waters. All the installed artificial plates have yielded spread-out particles of coccoid-like to irregular shapes of a few- $\mu$ m diameter after 12-15 year exposure. Also the synthetic Na-buserite crystals have accumulated various metallic elements after the exposure test. The evidence ascertained a proposed model of modern continuous precipitation of $\mathrm{Fe}-\mathrm{Mn}$ oxide from ambient waters forming piled ferromanganese crusts or nodules at a wide-range of depths including OMZ. The particles can be bacteria as optimal platforms for Fe-Mn minerals but do not indicate any direct evidences of accellerated microbial precipitation. 